\title{
A NEW APPROACH TO MICROBIAL PRODUCTION OF GALLIC ACID
}

\author{
Bhakti Bajpai $^{1 *}$; Shridhar Patil ${ }^{2}$ \\ ${ }^{1}$ School of Biotechnology, D.A.V.V., Indore - 452001, India; ${ }^{2}$ School of Life Sciences, D.A.V.V., Indore-452001, India.
}

Submitted: September 22, 2007; Returned to authors for corrections: November 22, 2007; Approved: October 22, 2008.

\begin{abstract}
In a new approach to microbial gallic acid production by Aspergillus fischeri $\mathrm{MTCC} 150,40 \mathrm{gL}^{-1}$ oftannic acid was added in two installments during the bioconversion phase of the process $\left(25 \mathrm{gL}^{-1}\right.$ and $15 \mathrm{gL}^{-1}$ at 32 and $44 \mathrm{~h}$ respectively). The optimum parameters for the bioconversion phase were found to be temperature: $35^{\circ} \mathrm{C}, \mathrm{pH}$ : slightly acidic (3.3-3.5), aeration: nil and agitation: $250 \mathrm{rpm}$. A maximum of $71.4 \%$ conversion was obtained after $71 \mathrm{~h}$ fermentation with $83.3 \%$ product recovery. The yield was $7.35 \mathrm{~g}$ of gallic acid per $\mathrm{g}$ of biomass accumulated and the fermenter productivity was $0.56 \mathrm{~g}$ of gallic acid produced per liter of medium per hour.
\end{abstract}

Key words: tannase, gallic acid, tannic acid, Aspergillus fischeri

\section{INTRODUCTION}

Gallic acid (3,4,5-trihydroxybenzoic acid) is an organic substance occurring in many plants either as a free molecule or as part of tannic acid molecule (Fig. 1). Gallic acid is extensively used as an ingredient of developer in photography and printing inks. It also serves as a precursor for the commercial production of an anti-microbial drug trimethoprim, a food - preservative propyl gallate and some dyestuffs (13). Besides this, gallic acid possesses wide range of biological activities, such as antioxidant, antibacterial, antiviral, analgesic etc. As antioxidant gallic acid acts as an antiapoptotic agent and helps to protect human cells against oxidative damage (17). Gallic acid is also found to show cytotoxic activity against cancer cells, without harming normal cells (11). Because of its several interesting properties and commercial applications, gallic acid is a compound of great interest to both pharmaceutical and chemical industries. Conventionally gallic acid is produced by acid hydrolysis of tannic acid but it has cost, yield and low purity disadvantages. Alternatively, gallic acid can be produced by the microbial hydrolysis of tannic acid by tannase (tannin-acylhydrolase EC 3.1.1.20), an inducible enzyme, secreted by microorganisms (12). Microbial production of tannase, especially from fungi, is well documented $(1,2,4,5,8,11,17)$, however, the reports on tannic acid hydrolysis is limited. Mainly Aspergilli have been used for hydrolysis of tannic acid to yield gallic acid

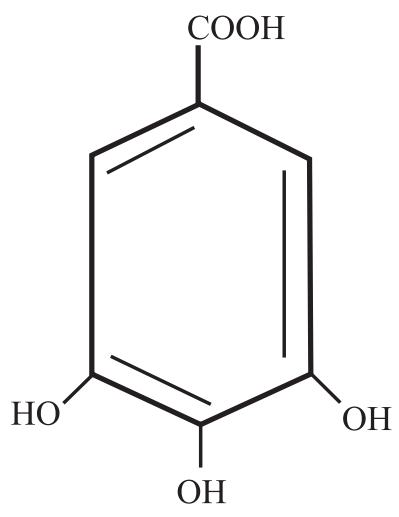

Figure 1.3,4,5-trihydroxybenzoic acid.

(13-15,18), among bacteria Klebsiella pneumoniae and Corynebacterium sp. have been reported to produce gallic acid from crude extract of tara gallotannin (6).

The current global requirement of gallic acid is around 8,000 tons/year and despite the immense commercial importance of gallic acid little work has been done on development of a process for gallic acid production at fermenter level $(13,18)$. The main hindrance in the development of a successful bioconversion process is the sensitivity of the microorganisms to tannic acid and the oxidation of the unused tannic acid. This limits the use

*Corresponding Author. Mailing address: School of Biotechnology, Devi Ahilya Vishwavidyalaya, Indore-452001, India. E-mail: bbajpai@yahoo.com 
of high tannic acid concentration during bioconversion process resulting in low productivity. Therefore, the authors have developed a strategy to overcome the above mentioned problems and achieve high percent conversion during bioconversion. The present study proposes a protocol for gallic acid production in a 5 liter fermenter at $40 \mathrm{gL}^{-1}$ of tannic acid concentration extracted from Quercus infectoria gall nuts using Aspergillus fischeri MTCC 150, a new fungus which has not been reported so far.

A strain of A.fischeri MTCC 150 showing high tannase activity at shake flask level was selected and maintained on PDA slants supplemented with $0.01 \%$ tannic acid. Dry powder of tannic acid was obtained by aqueous extraction of Chinese gall nuts $(Q$. infectoria) in a soxhlet apparatus. The tannin obtained was pentagalloyl glucose. Mineral salt medium was used for raising the inoculum as well as for fermentation. The composition of the medium was $\left(\mathrm{gL}^{-1}\right): \mathrm{NH}_{4} \mathrm{NO}_{3}, 1.65 ; \mathrm{KNO}_{3}$, $1.9 ; \mathrm{MgSO}_{4} .7 \mathrm{H}_{2} \mathrm{O}, 0.37 ; \mathrm{CaCl}_{2} .2 \mathrm{H}_{2} \mathrm{O}, 0.44 ; \mathrm{KH}_{2} \mathrm{PO}_{4}, 0.17$ and $(\mathrm{mg}$ $\left.\mathrm{mL}^{-1}\right): \mathrm{H}_{3} \mathrm{BO}_{3}, 6.2 ; \mathrm{MnSO}_{4} . \mathrm{H}_{2} \mathrm{O}, 16.9 ; \mathrm{ZnSO}_{4} .7 \mathrm{H}_{2} \mathrm{O}, 8.6$; $\mathrm{Na}_{2} \mathrm{MoO}_{4} .2 \mathrm{H}_{2} \mathrm{O}, 0.25 ; \mathrm{CuSO}_{4} .5 \mathrm{H}_{2} \mathrm{O}, 0.025 ; \mathrm{CoCl}_{2} .6 \mathrm{H}_{2} \mathrm{O}, 0.025$; $\mathrm{FeSO}_{4} .7 \mathrm{H}_{2} \mathrm{O}, 5.6$ and $\mathrm{Na}_{2}$ EDTA, 7.6 supplemented with 5.0g tannic acid $\mathrm{l}^{-1}$ of medium, as an inducer and $\mathrm{pH}$ 5.6.

The experiment was performed in a 5 liter capacity, top driven BIOFLO III, NBS fermenter. The bioconversion was divided into two phases: (1) Growth phase: Three liters of growth medium was inoculated with $300 \mathrm{~mL}$ of pre-induced, $30 \mathrm{~h}$ old culture of $A$. fischeri MTCC 150. The values of physical parameters during growth phase were - temperature: $30^{\circ} \mathrm{C}$, initial pH: 5.6, aeration: $1 \mathrm{vvm}$ and agitation: $300 \mathrm{rpm}$. (2) Bioconversion phase: During this phase tannic acid was added in two installments of $25 \mathrm{gL}^{-1}$ and $15 \mathrm{gL}^{-1}$ after $32 \mathrm{~h}$ and $50 \mathrm{~h}$ respectively. The values of physical parameters during this phase were- temperature: $35^{\circ} \mathrm{C}, \mathrm{pH}: 4.0$ to 3.5 (not regulated), aeration: nil, agitation: $250 \mathrm{rpm}$. The fermentation was stopped after $77 \mathrm{~h}$ of fermentation, when there was no significant increase in gallic acid formation. The samples were analyzed at regular intervals for biomass, residual tannic acid and gallic acid formed. Biomass was estimated by dry cell weight method at $105^{\circ} \mathrm{C}$, whereas, tannic acid and gallic acid were estimated by following the two wavelengths simultaneous estimation method of Bajpai and Patil (3).

Conc. of tannic acid $\left(\mathrm{mg} \mathrm{mL}^{-1}\right)=34.41\left(\mathrm{~A}_{293.8}\right)-6.98\left(\mathrm{~A}_{254.6}\right)$ Conc. of gallic acid $\left(\mathrm{mg} \mathrm{mL}^{-1}\right)=21.77\left(\mathrm{~A}_{254.6}\right)-17.17\left(\mathrm{~A}_{293.8}\right)$

The fermentation broth was filtered through the layers of muslin cloth and mycelial mass was washed with minimum quantity of hot water to remove the gallic acid deposited on the mycelium. For recovery of gallic acid from broth, the filtrate and washings were combined, $\mathrm{pH}$ was adjusted to 2.0 with $\mathrm{HCl}$ and kept at $0^{\circ} \mathrm{C}$. Gallic acid becomes unstable at low $\mathrm{pH}$ and precipitates out from the broth at $0^{\circ} \mathrm{C}$. The precipitate obtained was filtered under vacuum, then dissolved in minimum amount of acidified hot water and recrystallized at $4^{\circ} \mathrm{C}$.

The fermentation experiment was performed under the conditions optimized at shake flask level (data not shown) with few variations. The main hindrance in the development of a successful gallic acid production process is the oxidation of tannic acid. Considering the polyphenolic nature of tannic acid and gallic acid, $\mathrm{pH}$ of the medium was kept acidic despite the fact that the tannase activity is favored in alkaline $\mathrm{pH}$ (11). The aeration was put off few hours after addition of tannic acid to avoid the oxidation of residual tannic acid and gallic acid formed, which is a serious problem and hampers the yield. Further, to prevent the degradation of gallic acid formed by fungus via tricarboxylic acid cycle (16), anaerobic environment in the fermenter was maintained. Earlier experiments have revealed that optimum temperature for growth and tannase activity are different, therefore the temperature was raised from $30^{\circ} \mathrm{C}$ to $35^{\circ} \mathrm{C}$ after the growth phase was over.

Fig. 2 shows the effect of single dose and split dose addition of tannic acid on the pattern of gallic acid accumulation in the culture broth of A. fischeri MTCC 150 in a shake flask. It is clear from the figure that single dose addition of tannic acid had adverse effect on the activity of the fungus and the yield of gallic acid was increased by split dose addition of tannic acid. The low conversion value obtained with single dose addition of tannic acid is a direct reflection of toxic effect of high concentration of tannic acid on fungus, a fact that is supported by other workers also (7). Although fungus shows very high percent conversion $(75 \%)$ at low substrate concentration $(20$ $\mathrm{gL}^{-1}$ ) as compared to $23 \%$ conversion obtained at $50 \mathrm{gL}^{-1}$ tannic

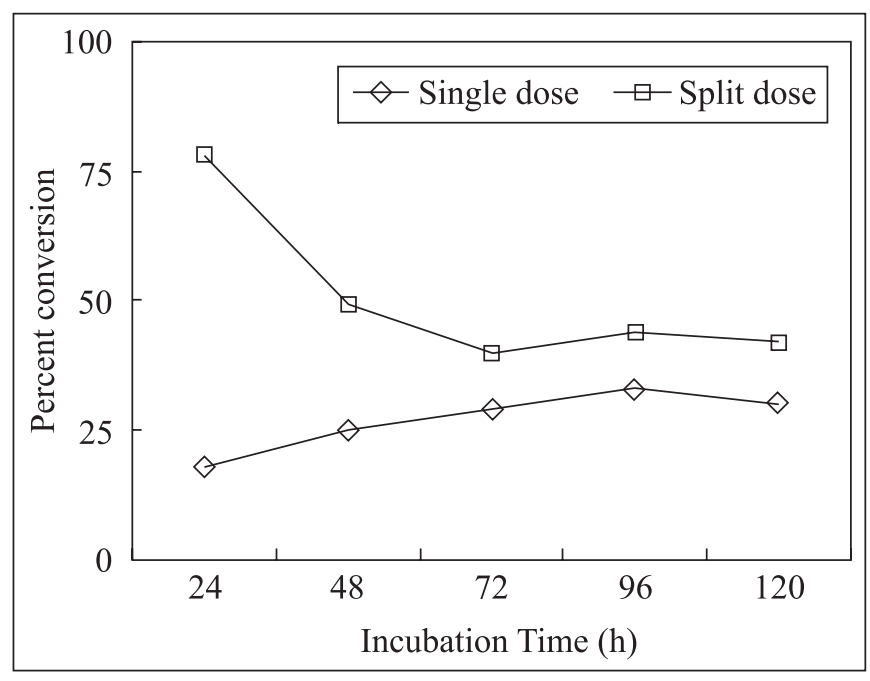

Figure 2. Effect of single dose and split dose addition of tannic acid on percent conversion of tannic acid into gallic acid by A.fischeri MTCC 150. 
acid but for a process to be economically viable it is imperative that the substrate concentration should be as high as possible to achieve high productivity.

The time course of $\mathrm{pH}$ values and mycelia dry weight during the bioconversion process is depicted in Fig. 3. A continuous increase in the mycelia dry weight was observed up to $35 \mathrm{~h}$ of fermentation, which remained constant thereafter. The growth of fungus was arrested after the addition of second installment of tannic acid in the medium. The medium $\mathrm{pH}$ showed a steep decline during growth phase indicating the metabolism of carbon source present in the medium and in the latter stages accumulation of gallic acid.

The estimated concentrations of residual tannic acid and gallic acid formed in the fermentation medium during bioconversion are shown in Fig. 4. A maximum conversion of $71.4 \%$ was reached after $37 \mathrm{~h}$ of tannic acid addition, which is significantly more as compare to $9.75 \%$ conversion obtained by Pourrat et al. (13) at 10\% tannic acid concentration. After the addition of first installment of tannic acid $\left(25 \mathrm{gL}^{-1}\right)$ initially the rate of hydrolysis was slow, similar observation was made after the addition of second installment of tannic acid $\left(15 \mathrm{gL}^{-1}\right)$. A continuous increase in gallic acid was noted up to $37 \mathrm{~h}$ of fermentation and then remained fairly constant. The fermentation was terminated when there was no increase in gallic acid content of the medium. The product recovery was $83.3 \%$ and purity of gallic acid was found to be $96 \%$. The yield was $7.35 \mathrm{~g}$ of gallic acid per $g$ of biomass accumulated and the fermenter productivity was $0.56 \mathrm{~g}$ of gallic acid produced per liter of medium per hour.

The present study recommends that to increase the yield of gallic acid two strategies should be adopted (i) the tannic acid should be added in installments after the growth phase is over and (ii) the aeration should be switched off after tannic acid addition.

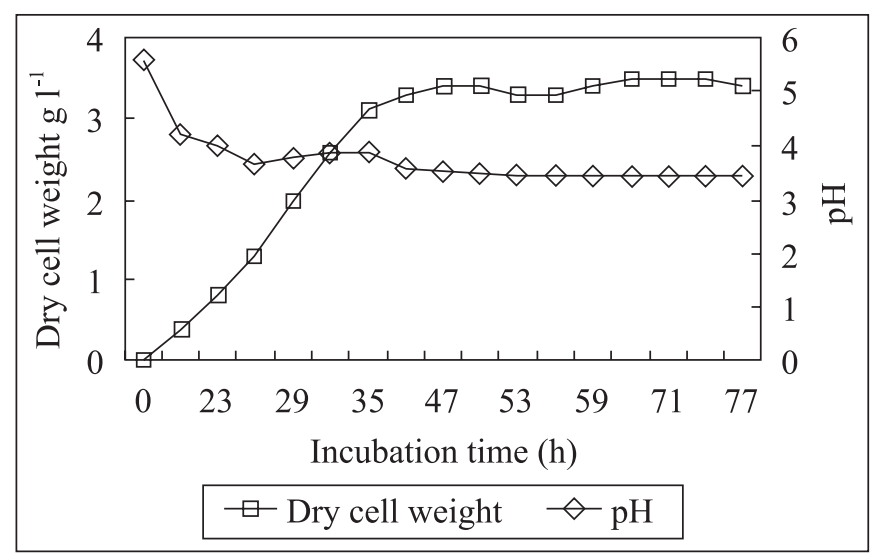

Figure 3. Time course of growth and $\mathrm{pH}$ values during bioconversion of tannic acid into gallic acid by $A$. fischeri MTCC 150 in a 5 liter fermenter.

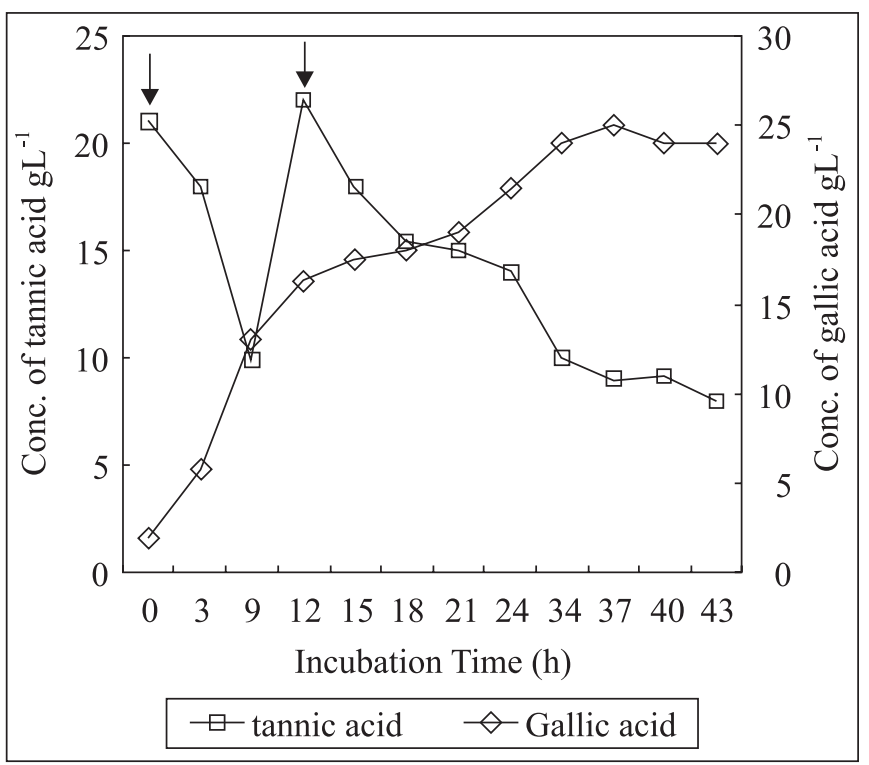

Figure 4. Concentrations of residual tannic acid and gallic acid formed during bioconversion process by A.fischeri MTCC 150 in a 5 liter fermenter. Tannic acid (4\%) was added in two installments of $25 \mathrm{gl}^{-1}$ and $15 \mathrm{gl}^{-1}$ after $32 \mathrm{~h}$ and $44 \mathrm{~h}$ growth respectively. $\downarrow$ Indicates addition of tannic acid.

\section{ACKNOWLEDGEMENTS}

Financial assistance to one of the author (Bhakti Bajpai) by Council of Scientific and

Industrial Research, New Delhi, India is thankfully acknowledged.

\section{RESUMO}

\section{Uma nova abordagem para produção microbiana de ácido gálico}

Em uma nova abordagem para produção de ácido gálico por Aspergillus fischeri MTCC 150, adiciona-se 40 g.L $\mathrm{L}^{-1}$ de ácido tânico em dois momentos da fase de bioconversão do processo ( 25 g.L. $\mathrm{L}^{-1} \mathrm{e} 15 \mathrm{~g} . \mathrm{L}^{-1}$ a $32 \mathrm{~h}$ e $44 \mathrm{~h}$, respectivamente). Os parâmetros ótimos para a fase de bioconversão foram: temperatura $35^{\circ} \mathrm{C}$, pH levemente ácido (3,3 a 3,5), nenhuma aeração e agitação 250 rpm. Um máximo de $71,4 \%$ de conversão foi obtido após $71 \mathrm{~h}$ de fermentação, com $83,3 \%$ de recuperação do produto. $\mathrm{O}$ rendimento foi $7,35 \mathrm{~g}$ de ácido gálico por g de biomassa acumulada e a produtividade do fermentador foi $0,56 \mathrm{~g}$ de ácido gálico por litro de meio por hora.

Palavras-chave: tanase, ácido gálico, acido tânico, Aspergillus fischeri 


\section{REFERENCES}

1. Aguilar, C.N.; Augur, C.; Favela-Torres, E.; Viniegra-Gonzalez, G. (2001). Production of tannase by Aspergillus niger Aa-20 in submerged and solid-state fermentation: influence of glucose and tannic acid. J. Industrial Microbiol. Biotechnol., 26 (5), 296-302.

2. Aissam, H.; Errachidi, F.; Penninckx, M.; Merzouki, M.; Benlemlih, M. (2005). Production of tannase by Aspergillus niger HA37 growing on tannic acid and Olive Mill Waste Waters W. J. Microbiol, Biotechnol., 21 (4), 609-614.

3. Bajpai, B.; Patil, S. (1996). Tannin acyl hydrolase (EC 3.1.1.20) activity of Aspergillus, Penicillium, Fusarium and Trichoderma. $W$. J. Microbiol. Biotechnol., 12 (3), 217-220.

4. Batra, A.; Saxena, R.K. (2005). Potential tannase producers from the genera Aspergillus and Penicillium. Process Biochem., 40 (5), 1553-1557.

5. Bradoo, S.; Gupta, R.; Saxena, R.K. (1997). Parametric optimization and biochemical regulation of extracellular tannase from $A$. japonicus. Process Biochem., 32 (2), 135-139.

6. Deschamps, A.M.; Lebeault, J.M. (1984). Production of gallic acid from tara tannin by bacterial strains. Biotechnol. Lett., 6, 237-242.

7. Ganga, P.S.; Nandy, S.C.; Santappa, M. (1977). Effect of environmental factors on the production of fungal tannase: Part I. Leather Sci., 24, 327-427.

8. Kar, B.; Banerjee, R. (2000). Biosynthesis of tannin acyl hydrolase from tannin rich forest residue under different fermentation conditions. J. Ind. Microbiol. Biotechnol., 25 (1), 29-38.

9. Lekha, P.K.; Lonsane, B.K. (1994). Comparative titers, location and properties of tannin-acyl-hydrolase produced by Aspergillus niger PKL 104 in solid-state, liquid- surface and submerged fermentations. Process Biochem., 29, 497-503.

10. Madlener, S.; Illmer, C.; Horvath, Z.; Saiko, P.; Losert, A.; Herbacek, I.; Grusch, M.; Elford, H.; Krupitza, G.; Bernhaus, A. (2007). Gallic acid inhibits ribonucleotide reductase and cyclooxygenases in human HL-60 promyelocytic leukemia cells. Cancer Lett., 245 (1-2), 156 162 .

11. Mondal, K.C.; Samanta, S.; Giri, S.; Pati, B.R. (2001). Distribution of tannic acid degrading microorganisms in the soil and comparative study of tannase from two fungal strains. Acta Microbiol., 50 (1), 75-82.

12. Pinto, G.A.S.; Leite, S.G.F.; Terzi1, S.Z.; Couri, S. (2001). Selection of tannase producing Aspergillus niger strains Brazilian J. Microbiol. $32,24-26$.

13. Pourrat, H.; Regerat, F.; Morvan, P.; Pourrat, A. (1987). Production of gallic acid from Rhus coriaria L. Biotechnol. Lett. 9, 731-734.

14. Pourrat, H.; Regerat, F.; Pourrat, A.; Jean, D. (1985). Production of gallic acid from tara tannin by a strain of Aspergillus niger. J. Ferment. Biotechnol., 63, 401-403.

15. Seth, M.; Chand, S. (2000). Biosynthesis of tannase and hydrolysis of tannins to gallic acid by Aspergillus awamori - optimization of process parameters. Process Biochem., 36 (1-2), 39-44.

16. Sohi, K.K.; Mittal, N.; Hundal, M.K.; Khanduja, K.L. (2003). Gallic acid, an antioxidant, exhibits antiapoptotic potential in normal human lymphocytes: A Bcl-2 independent mechanism. J. Nutr. Sci. Vitaminol., 49 (4), 221-227.

17. Treviño-Cueto, B.; Luis, M.; Contreras-Esquivel, J.C.; Rodríguez, R.; Aguilera, A.; Aguilar, C.N. (2006) Gallic acid and tannase accumulation during fungal solid state culture of a tannin-rich desert plant (Larrea tridentata Cov.) Bioresource Technol., 98 (3), 721 724.

18. Vermeire, A.; Vandamme, E. (1990). Fungal conversion of gallotannins into gallic acid. Ferment. Technol. Ind. Appl., 198203.

19. Watanabe, A. (1965). Studies on the metabolism of gallic acid by microorganisms. Part III. On the intermediary metabolism of gallic acid by Aspergillus. niger. Agr. Biol. Chem., 29, 20-26. 